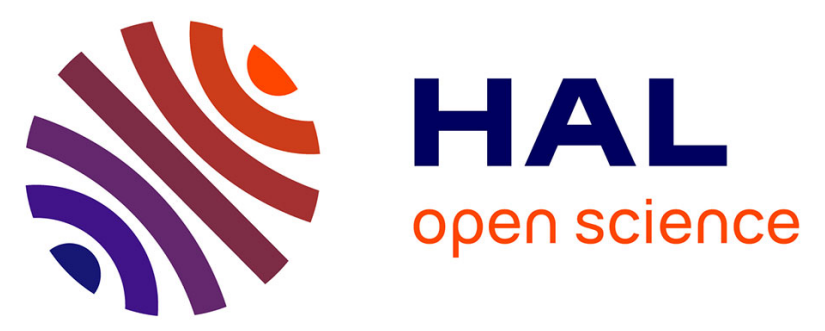

\title{
Potential role of soluble ST2 protein in idiopathic nephrotic syndrome recurrence following kidney transplantation.
}

Sarah Bruneau, Ludmilla Le Berre, Caroline Hervé, Asta Valanciuté, Maud Kamal, Jeanne Naulet, Laurent Tesson, Yohann Foucher, Jean-Paul Soulillou, Djillali Sahali, et al.

\section{To cite this version:}

Sarah Bruneau, Ludmilla Le Berre, Caroline Hervé, Asta Valanciuté, Maud Kamal, et al.. Potential role of soluble ST2 protein in idiopathic nephrotic syndrome recurrence following kidney transplantation.. American Journal of Kidney Diseases, 2009, 54 (3), pp.522-32. 10.1053/j.ajkd.2009.03.021. inserm-00418324

\section{HAL Id: inserm-00418324 https://www.hal.inserm.fr/inserm-00418324}

Submitted on 18 Sep 2009

HAL is a multi-disciplinary open access archive for the deposit and dissemination of scientific research documents, whether they are published or not. The documents may come from teaching and research institutions in France or abroad, or from public or private research centers.
L'archive ouverte pluridisciplinaire HAL, est destinée au dépôt et à la diffusion de documents scientifiques de niveau recherche, publiés ou non, émanant des établissements d'enseignement et de recherche français ou étrangers, des laboratoires publics ou privés. 


\section{High levels of soluble ST2 protein in recurrence of idiopathic nephrotic syndrome after kidney transplantation.}

Sarah Bruneau ${ }^{1}$, Ludmilla Le Berre ${ }^{1}$, Caroline Hervé ${ }^{1}$, Asta Valanciuté ${ }^{2}$, Maud Kamal ${ }^{2}$, Jeanne Naulet ${ }^{1}$, Laurent Tesson ${ }^{1}$, Yohann Foucher ${ }^{1}$, Jean-Paul Soulillou ${ }^{1}$, Djillali Sahali ${ }^{2}$ and Jacques Dantal ${ }^{1 *}$.

${ }^{1}$ INSERM, U643, Nantes, F44093 France; CHU Nantes, Institut de Transplantation et de Recherche en Transplantation (ITERT) Nantes, F44000 France; Université de Nantes, Faculté de Médecine, Nantes, F44000 France.

2 INSERM, U841 Eq 21, Créteil, F94010 France; Hôpital Henri Mondor, Créteil, F94010 France.

DS and JD contributed equally to this work.

This work was supported in part by "Fondation Progreffe" and AMGEN.

Running title: sST2 in INS recurrence

Word count: Text: 2737; Abstract: 238

\section{* Corresponding author:}

Pr. Jacques Dantal

ITERT/INSERM U643

CHU Hôtel Dieu

$30 \mathrm{Bd}$ Jean Monnet

44093 Nantes cedex 1 - France

Tel: +33 240087441

Fax: +33 240087411

Email: jacques.dantal@chu-nantes.fr 


\section{ABSTRACT}

After transplantation, corticosteroid-resistant Idiopathic Nephrotic Syndrome (INS) rapidly recurs in $30-50 \%$ of recipients, suggesting the presence of (a) circulating factor(s) which alter(s) the glomerular filtration barrier. In this paper, we investigated the possible implication of the soluble ST2 protein (SST2), a product of the c-maf pathway and a marker of Th2 cells, in the development of INS recurrence, as an association between INS relapse and an atypical Th2 polarization involving activation of c-maf has recently been reported. We analyzed SST2 levels in the serum of kidney recipients with INS as their primary kidney disease but with $(n=31)$ and without $(n=40)$ recurrence after transplantation and of recipients with primary glomerular diseases different from INS $(n=34)$. We found a significant increase of SST2 levels in the sera of patients suffering INS recurrence, but not in those of nonrecurrent INS and non-INS patients. No differences were detected in these sera before transplantation. Moreover, recurrent patients displayed the same SST2 isoform as the two control groups. In vitro, a mouse podocyte cell line was profoundly altered by incubation with sera of recurrent patients. However, purified SST2 from these patients was not able to reproduce these damages. In addition, induction of high SST2 levels in rats did not trigger proteinuria. Collectively, these data suggest that SST2 is a marker of INS recurrence that could be of interest for its diagnosis in ambiguous clinical situations. Nonetheless, SST2 does not seem to be directly implicated in INS development. 


\section{INTRODUCTION}

Idiopathic Nephrotic Syndrome (INS) is a glomerulopathy of unknown etiology characterized by a massive albuminuria without histological evidence of inflammatory injuries or immune complex deposits. Recently, genetic abnormalities have been shown to be involved in INS. However, patients with INS resistant to the treatments who progress to endstage renal failure with focal and segmental glomerular sclerosis (FSGS) usually do not exhibit gene alteration ${ }^{1,2}$. After transplantation, $30-50 \%$ of these patients develop a recurrence of their initial disease, leading to roughly $50 \%$ of graft lost ${ }^{3,4}$. In $90 \%$ of these patients, nephrotic syndrome recurs within the first hours after transplantation, suggesting the intervention of a circulating albuminuric factor. The beneficial effect of plasmapheresis also supports this hypothesis ${ }^{3-6}$. Several attempts have been made in order to determine the nature of this putative albuminuric factor, but its molecular characterization has remained elusive. We recently showed that the Buffalo/Mna rat strain spontaneously develop a nephrotic syndrome with a histological pattern closely similar to the human disease ${ }^{7}$. Moreover, we demonstrated the recurrence of proteinuria in Buffalo/Mna recipients of a normal rat kidney whereas nephrotic Buffalo/Mna kidneys recovered albuminuric permselectivity after transplantation in a normal recipient, suggesting the presence of extra renal factor(s) and making this strain the first possible relevant model of the human disease ${ }^{8}$.

The recent observation of an association between INS relapse and an atypical Th2 polarization, characterized by c-maf activation and IL-4 down regulation ${ }^{9}$, raises the question of implication of $\mathrm{T}$ cells in the pathophysiology of this disease. In this work, we have investigated the role of a putative soluble factor, SST2, whose promoter contains the c-maf recognition element (MARE) (DS, unpublished), as a candidate in the narrow but much selected population of INS recurrent patients after transplantation. In human, the ST2 gene encodes for two main products by alternative splicing: a transmembrane protein called ST2L, which is composed of an extracellular region with three immunoglobulin domains and of an intracellular toll-interleukin-1 receptor (TIR) domain, and a soluble secreted protein, SST2, which only includes the extracellular part of ST2L. The soluble form is secreted by activated Th2 cells which express ST2L at their surface ${ }^{10}$. In mice models, the ST2 protein has been described as a stable marker of a subset of activated Th2 cells independent of the production of IL-4, IL-5 and IL-10 11 , although it is not an universal marker of this T cell phenotype. Several investigations have reported an important role for ST2 in allergic airway inflammation ${ }^{12-14}$, and it is well known that there is a relationship between respiratory allergy and proteinuria in some cases of nephrotic syndrome. We and other authors have showed that ex vivo immunoadsorption of the plasma of patients with recurrent nephrotic syndrome 
onto protein A or anti-human immunoglobulin columns transiently decreases or abolishes proteinuria ${ }^{15}$. Interestingly, it has been found that the ST2 protein binds these proteins in vitro (DS, unpublished). The fact that SST2 is both associated with Th2 biased immune response and that this protein also binds to protein A makes it a candidate for a role in INS pathology and particularly in recurrence.

In this paper, we investigate the possibility of a role of SST2 in INS recurrence in human recipients with INS recurrence as well as in Buffalo/Mna rats. We report that INS recurrence after transplantation is strongly associated with an overexpression of the SST2 protein in recipients' blood, reinforcing the observation of a Th2 polarization associated with INS. Nonetheless, we were not able to demonstrate that SST2 directly affects the glomerular filtration barrier in vivo, or that this factor is responsible for the podocyte cell line alteration induced by sera from recipients with INS recurrence. Collectively, our results suggest that an elevated SST2 level is a marker for INS recurrence after transplantation in human that may be useful for its diagnosis in ambiguous clinical situations. 


\section{RESULTS}

\section{High sST2 levels are associated with INS recurrence after renal transplantation:}

SST2 serum concentrations were measured before and after renal transplantation in three clinical situations: 1/ patients with INS recurrence, 2/ patients with INS non-recurrence and $3 /$ patients with non-INS disease on native kidneys and who displayed high proteinuria levels from different origins after transplantation. The clinical characteristics of these patients are summarized in Table 1 . We did not detect significant differences in serum SST2 concentrations between these three cohorts before transplantation (Figure 1). In contrast, SST2 levels were strongly increased in recurrent patients after transplantation (median = $617.5 \mathrm{pg} / \mathrm{mL}$ vs. $124 \mathrm{pg} / \mathrm{mL}$ before transplantation, $P<0.01$ ), while they remained low in the comparison in the non-recurrent group (median $=23 \mathrm{pg} / \mathrm{mL}, P<0.001$ ) and in the group of patients without INS (median $=158.5 \mathrm{pg} / \mathrm{mL}, P<0.01$ ).

Determination of the capacity of SST2 concentrations to distinguish INS recurrence and INS non-recurrence by ROC curve analysis (Figure $2 \mathrm{~A}$ ) revealed an excellent discriminative power ( $A \cup C=0.9,95 \%$ confidence interval $79 \%-99 \%$ ), with a sensitivity of $80 \%$ and a specificity of $97 \%$ at a cut-off value of $205 \mathrm{pg} / \mathrm{mL}$ of circulating sST2. The ROC curve analysis was then applied to compare patients with INS recurrence and patients with non-INS glomerular diseases, who both displayed similar proteinuria levels after transplantation. As shown in figure $2 \mathrm{~B}$, SST2 levels also discriminated these two cohorts (AUC $=0.75,95 \%$ confidence interval $59 \%-89 \%$ ), with a sensitivity of $55 \%$ and a specificity of $86 \%$ at a cut-off value of $602 \mathrm{pg} / \mathrm{mL}$ of serum sST2.

Altogether, these results point out that post-transplantation recurrence is tightly associated with an upregulation of SST2 in patients with INS, and that measurement of SST2 levels in proteinuric patients after transplantation could discriminate recurrent patients from the others. Moreover, these observations raise the question of a potential involvement of the sST2 protein in the development of this disease.

\section{Recipients with recurrent INS do not accumulate a specific sST2 isoform:}

The possibility of an abnormal SST2 isoform was suggested by the absence of proteinuria in some patients with high SST2 levels (allergic diseases). SST2 immunopurified from the plasma of a patient with INS recurrence and a high SST2 level was analyzed by bidimensional electrophoresis (Figure 3). Several clusters of spots were detected, but only three of them had a degree of intensity allowing the analysis. The cluster \#1 presented the same characteristics as those described for SST2 of the "normal" human serum, i.e. a molecular weight of $57 \mathrm{kDa}$ and an isoelectric point of 8.40 (as described in the SwissProtExpasy database). The two other clusters had only one feature closed to the normal SST2 
protein: the isoelectric point for the cluster \#2 (approximately 8.00), and the molecular weight for the cluster \#3 (about $60 \mathrm{kDa}$ ). These three clusters were therefore analyzed by mass spectrometry (LC-ESI-MS/MS). Upon sequencing, the SST2 protein was detected only in the cluster \#1 (Table 2), presenting all the expected characteristics and electrophoretic behavior, suggesting that recurrent patients display the normal isoform of the SST2 protein.

\section{Sera from patients with INS recurrence but not sST2 induce podocyte cell line injury in} vitro:

An immortalized mouse podocyte cell line ${ }^{16}$ was used to investigate whether the serum and purified SST2 of recurrent patients could alter morphological and/or functional characteristics of podocytes. Incubation of these cells with serum or plasma from recurrence induced cell body contraction, nucleus retraction and loss of cell processes (Figure 4), whereas the cell morphology was well conserved in podocytes exposed to serum from nonrecurrence, confirming a previous report ${ }^{17}$. However, we found these modifications with only $70 \%$ of the sera from recurrence tested, which may point out a limit in the sensitivity of this test. In contrast, we found no podocyte injury after incubation with sera from patients without recurrence. Analysis by dual-labelling immunofluorescence of the cell distribution of F-actin and vinculin showed some major architectural modifications of podocytes incubated with reactive sera from recurrent patients. Indeed, incubated podocytes exhibited a considerable redistribution of actin filaments around the nucleus, with a rarefaction of cortical actin and a scarce expression of vinculin (Figure 4B). In contrast, podocytes incubated with serum from patients with non-recurrence displayed a normal phenotype. Altogether, these results support the concept that serum and plasma of INS recurrent patients contain factor(s) capable to directly induce podocytes morphological damages.

In order to determine whether the SST2 protein was implicated in the podocyte injuries we observed in vitro, we purified SST2 from reactive plasmas and tested the activity of the different fractions (initial plasma, plasma SST2-depleted and purified SST2 protein) on differentiated podocytes. We found that podocytes exposed to SST2-depleted plasma exhibited the same architectural modifications than podocytes incubated with the primitive plasma (Figure 5). Furthermore, podocytes exposed to SST2 proteins purified from the same samples displayed a normal phenotype, showing that SST2 is not the serum toxic fraction in recurrent patients.

\section{Achieving high sST2 circulating levels does not trigger proteinuria in rat:}

Because the absence of in vitro effect of SST2 on the mouse podocyte cell line does not necessarily exclude a role for SST2 in INS recurrence, we also investigated whether this protein could induce proteinuria and glomerular damages in rat. To do so, we used two 
experimental approaches. First, we treated Sprague-Dawley rats with an adeno-associated virus coding for the human SST2 protein. Administration of this AAV intravenously did not induce proteinuria in these rats (Figure 6B), despite induction of high circulating SST2 levels (Figure 6A). Second, we injected directly into the renalry of healthy Lewis $1 \mathrm{~W}$ rat the totality of SST2 purified from the blood of another Lewis $1 \mathrm{~W}$ rat or of a nephrotic Buffalo/Mna rat in order to focus as much as possible the potential effects of this protein on the kidney. Figure 7 shows that the increase in blood concentration of SST2 was not associated with an increase in urinary protein. This was the case both for injection of SST2 purified from Lewis $1 \mathrm{~W}$ rats or from Buffalo/Mna rats.

Altogether, these results do not suggest that SST2 acts directly on the kidney to induce the development of INS recurrence after transplantation. 


\section{DISCUSSION}

Idiopathic Nephrotic Syndrome is a heterogeneous disease. In non genetic forms, the primary disorder seems to involve the immune system. To date, little is known about immune mechanisms which ultimately lead to the disorganisation of the glomerular filtration barrier and since the first report of INS recurrence following renal transplantation, the pathophysiology of this disease has become a challenge for nephrologists ${ }^{18}$. It has been postulated for a long time that INS results from a T cell dysfunction, leading to the release of a circulating factor responsible for glomerular damages ${ }^{19}$. In this regard, INS patients with recurrence after transplantation represent an interesting "model" in which an immune origin is highly suggested. Over the past 30 years, several teams, including ours, attempted without success to identify a circulating factor in INS. On the basis of an active serum component binding to protein A affinity columns, we have suggested that the permeability factor displays some immunoglobulin-like properties ${ }^{6}$. These findings were also supported by Savin's team which also suggested that a circulating factor with an apparent molecular weight around 50 $\mathrm{kDa}^{5}$ binds to protein $\mathrm{A}$. We first stated the hypothesis that the SST2 protein could be the factor, whose identity had been approached in these works, since it contains three Ig-like domains, binds with high affinity to protein A and displays a molecular weight of $57 \mathrm{kDa}$. In addition, a role for SST2 in INS recurrence was also suggested in a study using a subtractive cDNA library screening technique on peripheral blood mononuclear cells (PBMC), showing that the transcription factor c-maf was up regulated during INS relapse compared with remission ${ }^{9}$. Despite the fact that SST2 was not found increased in this previous study, this observation enables an interesting connexion with the ST2 protein, whose gene promoter contains the c-maf recognition element (MARE) (DS, unpublished). Moreover, several studies pointed out the ST2 protein as a selective marker of Th2 cells $s^{10-11,20-21}$, which correlates with the atypical Th2 polarization described in INS ${ }^{22-24}$. Finally, SST2 seems to be tightly associated with allergic airways inflammation ${ }^{12-14}$, which have also been associated with some cases of nephrotic syndrome ${ }^{25-27}$.

In this study, we reported that the SST2 production is strongly increased after transplantation in recipients with INS recurrence. In contrary, non-recurrent and non-INS patients have no elevated serum SST2 levels. On the basis of ROC analysis, we found that the recurrence phenomenon is significantly associated to SST2 concentrations after transplantation. Moreover, this up regulation does not correlate to the level of proteinuria (data not shown). This augmentation can not be due to the immunosuppressive treatment, known to raise Th2 responses, as the two other groups tested were also treated with calcineurin inhibitors and antimetabolic drugs. The use of corticosteroids was less frequent in 
non-recurrent patients but was the same between INS recurrent patients and non-INS controls. Globally, these first experiments suggested that patients with a high blood SST2 concentration after transplantation are likely undergoing INS recurrence. Unfortunately, we detected no difference between the tested groups before transplantation, precluding relevance of SST2 levels measurement as a predictability test for INS recurrence.

Since increased production of SST2 appears associated with INS recurrence, we tested the hypothesis that this protein could be a permeability factor related to the development of INS. However, since SST2 is also increased in the sera of patients in acute pathological conditions such as myocardial infarction, sepsis, trauma or exacerbation of idiopathic pulmonary fibrosis ${ }^{28-30}$, all clinical situations not associated with proteinuria, the possibility of the existence of an abnormal SST2 isoform in recurrent INS patients was studied in a caricatural recurrent patient with a high circulating SST2 level. The bidimensional analysis of the SST2 protein purified from the plasma of this patient revealed the same isoform as described in healthy individuals.

To further explore a putative role of SST2 in INS recurrence, the serum activity from recurrent and non-recurrent patients was tested on a mouse podocyte cell line before and after SST2 depletion, as well as the SST2 protein alone purified from these sera. As Saleem's team which had underlined the toxic activity of nephrotic plasma on the human podocyte cell line $^{17}$, we also found significant morphological damages in podocytes incubated with sera from patients with recurrence, whereas cells exposed to sera from non-recurrent patients exhibited a normal morphology. However, despite the serum activity was exclusively restrained to sera from patients with recurrence, we found a low sensitivity of this assay, as several sera from recurrent patients were not able to induce these podocyte damages. However, this could be due to the use of a mouse cell line with human sera, in contrary to Saleem who used human podocytes. Plasmas of recurrent patients, which presented an activity in vitro were then SST2-depleted and tested again on podocytes. Eluates containing purified SST2 proteins were not toxic, whereas the initial activity was present in SST2depleted plasmas.

Finally, we tested the SST2 activity in vivo in Sprague-Dawley rats, using an adenoassociated virus containing the human SST2 gene sequence. Despite a high and durable expression of the SST2 protein, these animals did not develop proteinuria. However, to avoid a specie specific effect, we also injected the SST2 protein purified from healthy Lewis $1 \mathrm{~W}$ or nephrotic Buffalo/Mna rats sera directly in the renal artery of Lewis $1 \mathrm{~W}$ rats. Nevertheless, these animals did not develop proteinuria, whether the SST2 proteins came from Lewis $1 \mathrm{~W}$ or SST2 from Buffalo/Mna rats, further suggesting that this protein alone is not capable to induce kidney damages. 
Altogether, these results showed that although sST2 is strongly increased in recurrent INS patients after transplantation, this protein does not seem to be directly implicated in the development of nephrotic proteinuria. SST2 is known to be strongly upregulated in the sera of patients with various disorders associated with an abnormal Th2 response, including systemic lupus erythematosus, asthma and idiopathic pulmonary fibrosis ${ }^{30-32}$. In the case of INS recurrence, this augmentation might also not be the cause of the disease, but rather a reflection of an atypical Th2 activation. 


\section{PATIENTS, MATERIALS AND METHODS}

Patients: 71 patients suffering from biopsy proven corticosteroid resistant INS and who had undergone a kidney transplantation from September 1983 to April 2007 were included in this study. Patients who presented an immediate proteinuria after transplantation, persisting above $3 \mathrm{~g} / \mathrm{d}$ at one month, with a kidney graft biopsy showing minimal change glomerulonephritis or isolated FSGS lesions without other transplant specific lesion, were defined as recurrent patients $(R, n=31)$. All patients were treated with an immunosuppressive regimen including calcineurin inhibitors $(\mathrm{CNI})$ and antimetabolic drugs (Mycophenolate Mofetil or Azathioprin) and/or by plasmapheresis or immunoadsorption. Pre transplant sera were collected within the 12 hours before surgery, and kept frozen at $-20^{\circ} \mathrm{C}$. At post transplantation serum harvesting, recurrent patients presented a persistent proteinuria above $2 \mathrm{~g} / \mathrm{d}$. On the contrary, non-recurrent INS patients $(N R, n=40$ ) displayed less than $1 \mathrm{~g} / \mathrm{d}$ of proteinuria one week after transplantation, and remained below $0.5 \mathrm{~g} / \mathrm{d}$ at any times thereafter. The control group consisted of 34 proteinuric transplanted patients with non-INS related end stage renal failure (diabetes, uropathy, IgA glomerulonephritis, nephroangiosclerosis, chronic interstitial nephropathy, renal polykystosis) (Table 1). In this group, the proteinuria was related to different kidney graft lesions: allograft glomerulonephritis, recurrence of IgA nephritis or diabetes.

All of these patients gave informed consent to this study according to French legislative guidelines.

Quantification of human sST2 protein: The concentration of soluble ST2 protein in the sera of INS patients and controls was determined with a commercial enzyme-linked immunosorbent assay (ELISA, R\&D Systems) as per manufacturer's instructions. The sensitivity of this test is $25 \mathrm{pg} / \mathrm{ml}$.

Purification of human or rat sST2: In human, ST2 immunoaffinity column was prepared by coupling $150 \mu \mathrm{g}$ of anti-human ST2 antibody (R\&D Systems) onto agarose beads, using sodium cyanoborohydride, as directed by Seize Primary Immunoprecipitation Kit instructions (Pierce). Plasmas from recurrent INS patients were filtered through $0.22 \mu \mathrm{m}$ filters and passed through the immunoaffinity column using a peristaltic pump at a flow rate of 0.5 $\mathrm{mL} / \mathrm{min}$. After washing with PBS, bound proteins were eluted in $0.1 \mathrm{M}$ glycine. Ten fractions of $250 \mu \mathrm{L}$ were collected, pooled and subjected to trichloroacetic acid (TCA) precipitation before bidimensional electrophoresis, or neutralized by adding $10 \mu \mathrm{L}$ of $1 \mathrm{M} \mathrm{Na}_{2} \mathrm{HPO}_{4}$ for in vitro experiments. 
In rats, serum was prepared from Lewis $1 \mathrm{~W}$ or Buffalo/Mna rats blood and SST2 was purified as for human plasma using an immunoaffinity column prepared by coupling anti-rat ST2 antibody (Santa Cruz Biotechnology) onto agarose beads. Elution fractions were collected in cellulose tubular membranes (molecular weight cut-off $=12000 \mathrm{D}$, Interchim), concentrated three-fold using polyethylene glycol (PEG) (molecular weight $35000 \mathrm{D}$, Merck), and dialyzed against PBS ( 3 changes) for 2 days. Purified sST2 from one animal (around $35 \mathrm{ng}$ ) was kept to be injected in the renal artery of one Lewis $1 \mathrm{~W}$ rat.

Bidimensional electrophoresis: Eluted fractions from the human ST2 immunoaffinity column were precipitated with $20 \%$ TCA, for 30 min on ice. After centrifugation at 14,000 rpm at $4^{\circ} \mathrm{C}$ for $15 \mathrm{~min}$, the pellet was washed twice with $100 \%$ cold acetone, and the final pellet was rehydrated for $20 \mathrm{~min}$ in $180 \mu \mathrm{L}$ of $8 \mathrm{M}$ Urea, 2\% CHAPS (w/v), $50 \mathrm{mM}$ dithiothreitol, $0.2 \%$ Bio-Lyte $3 / 10$ ampholytes (w/v) and $0.01 \%$ bromophenol blue (w/v) (Bio-Rad). The sample was loaded on an immobilized $\mathrm{pH}$ gradient gel strip ( $\mathrm{pH} 3$ to 10; Bio-Rad), and isoelectric focusing was conducted in the IPGphor system (Amersham Biosciences) using the following steps: $20 \mathrm{~V}$ for $12 \mathrm{~h} ; 500 \mathrm{~V}$ for $1 \mathrm{~h} ; 1000 \mathrm{~V}$ for $1 \mathrm{~h} ; 6000 \mathrm{~V}$ for $4 \mathrm{~h}$. Afterwards, the strip was equilibrated for $10 \mathrm{~min}$ at room temperature (RT) with equilibration buffer (50 $\mathrm{mM}$ Tris- $\mathrm{HCl} \mathrm{pH}$ 8.8, $6 \mathrm{M}$ Urea, 30\% Glycerol (v/v), 2\% SDS (w/v)) containing 1\% DTT (w/v), and then 10 min at RT with equilibration buffer containing $2 \%$ lodoacetamide (w/v). The strip was sealed with $0.1 \%$ agarose containing $0.005 \%$ of bromophenol blue, at the top a $10 \%$ SDS-PAGE precast gel (Bio-Rad), and electrophoresis was performed using a Criterion System (Bio-Rad) until the bromophenol blue reached the bottom of the gel. Finally, the gel was fixed and stained for $2 \mathrm{~h}$ in $25 \%$ ethanol, 10\% acetic acid, $0.2 \%$ Comassie Blue, and destained in 25\% ethanol, $10 \%$ acetic acid.

Mass spectrometry: Spots of interest were manually excised from the gel. Proteins contained in these spots were submitted to trypsin digestion and their identity was confirmed by LC-ESI-MS/MS. Briefly, peptides were separated by high performance liquid chromatography (HPLC) on a $75 \mu \mathrm{m} \times 15 \mathrm{~mm}$ Pepmap C18 reversed-phase column and elution was performed with a gradient of acetonitrile/water $0.1 \%$ formic acid. Peptides were then submitted to sequencing on a Q-TOF Globa spectrometer and analyzed with OVNIp software (INRA, Nantes, France). Digestion, HPLC and sequencing were performed at the Biopolymers - Interactions - Structural Biology Platform at the INRA research center (Nantes, France).

Mouse podocyte cell culture: A previously described conditionally immortalized mouse podocyte cell line ${ }^{16}$ was routinely maintained in RPMI-1640 medium (Sigma) containing 100 
$\mu \mathrm{g} / \mathrm{mL}$ streptomycin, $100 \mathrm{U} / \mathrm{mL}$ penicillin (Sigma) and 10\% foetal calf serum (FCS, Abcys). Podocytes were propagated on collagen l-coated plates (R\&D Systems) at $33^{\circ} \mathrm{C}$ in the presence of $10 \mathrm{U} / \mathrm{mL}$ of recombinant mouse $\gamma$-interferon (R\&D Systems). Removal of $\gamma$ interferon and temperature switch to $37^{\circ} \mathrm{C}$ inactivated the SV40 T antigen and induced podocytes differentiation in 14 days.

In vitro effect of plasmas and sST2 on podocytes: After day 14 of podocytes differentiation, FCS of the medium was substituted with the same concentration (10\%) of human plasma or serum from INS patients with or without recurrence. Plasmas which had a significant effect on podocytes were also tested after immunoadsorption of the SST2 proteins they contained, in parallel with this purified SST2. After $48 \mathrm{~h}$ of incubation, cells were fixed in 4\% paraformaldehyde for 20 minutes for immunofluorescence staining: after blocking 30 minutes with $10 \%$ NGS, podocytes were stained with TRITC-labeled phalloidin (Sigma) for Factin cytoskeleton visualization, with a monoclonal anti-vinculin antibody (Sigma) and the appropriate FITC-conjugated secondary antibody for the detection of the points of contact between the actin cytoskeleton and the extracellular matrix, and with DAPI for nuclear staining.

\section{In vivo effect of sST2 in rat:}

Animals: Overexpression of SST2 was induced through an AAV in healthy male SpragueDawley rats (Janvier, Le Genest Saint Isle, France), or by injection in healthy male Lewis $1 \mathrm{~W}$ rats (Janvier, Le Genest Saint Isle, France) of the purified SST2 protein from other Lewis $1 \mathrm{~W}$ rats or from nephrotic 6 months-old male Buffalo/Mna rats. The Buffalo/Mna strain maintained in our lab was originally kindly provided by Dr Saito (Central Experimental Institute, Nokawa, Kawasaki, Japan). At the time of experimentation, Buffalo/Mna rats displayed a proteinuria level between 0.4 and $0.8 \mathrm{~g} / \mathrm{mmol}$. The animal care was in accordance with our national institutional guidelines.

Construction of the AAV8-hST2 vector: AAV8 vector expressing human SST2 (hST2) driven by the ubiquitous RSV promoter was generated in the pZA-RSV-WPRE vector. For that, hST2 cDNA fragment (995 bp) was removed from pEFBOS-hST2 ${ }^{33}$ using BstXI, blunted and ligated downstream the RSV promoter and the chimeric intron into pZA-RSV-WPRE cut by EcoRI and BamHI and blunt-ended to give the PZA-RSVhST2WPRE. AAV8 vector contains also the woodchuck hepatitis virus posttranscriptional regulatory element (WPRE) and SV40 polyadenylation signal flanked by inverted tandem repeats (ITRs). Recombinant AAV8 were manufactured as described elsewhere ${ }^{34}$ and purified by cesium chloride density gradients followed by extensive dialysis against PBS. 
Intra-arterial injection of purified rat SST2: Intra-arterial injection was chosen to optimize the exposure of the kidney to SST2 proteins. After measuring their preinjection proteinuria levels, animals were anesthetized with isofluorane, a right nephrectomy was performed, the aorta was clamped above and below the left renal artery and $600 \mu \mathrm{L}$ of purified SST2 was slowly injected into the aorta left renal artery segment. Total time of ischemia was about 10 minutes. After recovering, rats were placed in metabolic cages in order to collect their urine $24 \mathrm{~h}$ after the injection, and to measure diuresis. Over-all, two groups of 5 rats received purified SST2 from Lewis $1 \mathrm{~W}$ and Buffalo/Mna. Control rats were injected with the same volume of an isotonic saline solution with the same procedure.

Proteinuria measurements: Rats were placed in metabolic cages for $24 \mathrm{~h}$ with free access to water but without food pellets which could fall into the urine collector and contaminate the samples. The total urinary protein concentration ( $g / L)$ was measured by a colorimetric method using a Hitachi autoanalyser (Boehringer). The urinary creatinine ( $\mathrm{mmol} / \mathrm{L})$ was measured by the Jaffé method. Proteinuria was expressed according to this formula: Proteinuria $(\mathrm{g} / \mathrm{mmol})=$ urinary proteins $(\mathrm{g} / \mathrm{L}) /$ urinary creatinine $(\mathrm{mmol} / \mathrm{L})$. It was considered as abnormal when the value was above $0.2 \mathrm{~g} / \mathrm{mmol}$.

Statistical analyses: The nonparametric Wilcoxon rank-sum test was used to compare SST2 levels between each cohort of patients. Receiver-Operating-Characteristic (ROC) curve analysis was performed with R software (http://www.r-project.org/) to determine the cut-off points of SST2 concentration in the serum that yielded the highest combined sensitivity and specificity in diagnosis of INS recurrence (see Figure 2 legend for explanations).

For comparison of rats' proteinuria levels before and at different points after injection of the AAV8-hST2 or purified SST2 protein, the Friedman test and a Dunn's multiple comparison test were used.

For each statistical test, $P$ values under 0.05 were considered to be significant. 


\section{ACKNOWLEDGEMENTS}

We would like to thank Pr. Christophe LEGENDRE (Hôpital Necker, Paris), Dr. Nicole LEFRANCOIS (Hôpital E. Herriot, Lyon), Pr. Georges MOURAD (Hôpital Lapeyronie, Montpellier) and Pr. Pierre MERVILLE (Hôpital Pellegrin, Bordeaux) for the help provided in the acquisition of serum samples and patient's consent, and Dr. Moin SALEEM for kindly providing the immortalized mouse podocyte cell line.

We thank Joanna Ashton-Chess for her help in editing the manuscript.

Financial conflict of Interest: None 


\section{REFERENCES}

1. Niaudet, P: [Lipoid nephrosis in childhood]. Rev Prat 53:2027-32, 2003

2. Nakayama, M, Katafuchi, R, Yanase, T, Ikeda, K, Tanaka, H \& Fujimi, S: Steroid responsiveness and frequency of relapse in adult-onset minimal change nephrotic syndrome. Am J Kidney Dis 39:503-12, 2002

3. Dantal, J, Baatard, R, Hourmant, M, Cantarovich, D, Buzelin, F \& Soulillou, JP: Recurrent nephrotic syndrome following renal transplantation in patients with focal glomerulosclerosis. A one-center study of plasma exchange effects. Transplantation 52:827-31, 1991

4. Pinto, J, Lacerda, G, Cameron, JS, Turner, DR, Bewick, M \& Ogg, CS: Recurrence of focal segmental glomerulosclerosis in renal allografts. Transplantation 32:83-9, 1981

5. Savin, VJ, Sharma, R, Sharma, M, McCarthy, ET, Swan, SK, Ellis, E, Lovell, H, Warady, B, Gunwar, S, Chonko, AM, Artero, M \& Vincenti, F: Circulating factor associated with increased glomerular permeability to albumin in recurrent focal segmental glomerulosclerosis. $N$ Engl J Med 334:878-83, 1996

6. Dantal, J, Bigot, E, Bogers, W, Testa, A, Kriaa, F, Jacques, Y, Hurault de Ligny, B, Niaudet, P, Charpentier, B \& Soulillou, JP: Effect of plasma protein adsorption on protein excretion in kidney-transplant recipients with recurrent nephrotic syndrome. $N$ Engl J Med 330:7-14, 1994

7. Nakamura, T, Oite, T, Shimizu, F, Matsuyama, M, Kazama, T, Koda, Y \& Arakawa, M: Sclerotic lesions in the glomeruli of Buffalo/Mna rats. Nephron 43:50-5, 1986

8. Le Berre, L, Godfrin, Y, Perretto, S, Smit, H, Buzelin, F, Kerjaschki, D, Usal, C, Cuturi, C, Soulillou, JP \& Dantal, J: The Buffalo/Mna rat, an animal model of FSGS recurrence after renal transplantation. Transplant Proc 33:3338-40, 2001

9. Valanciute, A, le Gouvello, S, Solhonne, B, Pawlak, A, Grimbert, P, Lyonnet, L, Hue, S, Lang, P, Remy, P, Salomon, R, Bensman, A, Guellaen, G \& Sahali, D: NF-kappa B p65 antagonizes IL-4 induction by c-maf in minimal change nephrotic syndrome. $J$ Immunol 172:688-98, 2004

10. Lecart, S, Lecointe, N, Subramaniam, A, Alkan, S, Ni, D, Chen, R, Boulay, V, Pene, J, Kuroiwa, K, Tominaga, S \& Yssel, H: Activated, but not resting human Th2 cells, in contrast to Th1 and T regulatory cells, produce soluble ST2 and express low levels of ST2L at the cell surface. Eur J Immunol 32:2979-87, 2002

11. Lohning, M, Stroehmann, A, Coyle, AJ, Grogan, JL, Lin, S, Gutierrez-Ramos, JC, Levinson, D, Radbruch, A \& Kamradt, T: T1/ST2 is preferentially expressed on murine Th2 cells, independent of interleukin 4, interleukin 5, and interleukin 10, and important for Th2 effector function. Proc Natl Acad Sci U S A 95:6930-5, 1998

12. Coyle, AJ, Lloyd, C, Tian, J, Nguyen, T, Erikkson, C, Wang, L, Ottoson, P, Persson, P, Delaney, T, Lehar, S, Lin, S, Poisson, L, Meisel, C, Kamradt, T, Bjerke, T, Levinson, D \& Gutierrez-Ramos, JC: Crucial role of the interleukin 1 receptor family member T1/ST2 in T helper cell type 2-mediated lung mucosal immune responses. J Exp Med 190:895-902, 1999

13. Lambrecht, BN, De Veerman, M, Coyle, AJ, Gutierrez-Ramos, JC, Thielemans, K \& Pauwels, RA: Myeloid dendritic cells induce Th2 responses to inhaled antigen, leading to eosinophilic airway inflammation. J Clin Invest 106:551-9, 2000

14. Gajewska, BU, Swirski, FK, Alvarez, D, Ritz, SA, Goncharova, S, Cundall, M, Snider, DP, Coyle, AJ, Gutierrez-Ramos, JC, Stampfli, MR \& Jordana, M: Temporal-spatial analysis of the immune response in a murine model of ovalbumin-induced airways inflammation. Am J Respir Cell Mol Biol 25:326-34, 2001 
15. Dantal, J, Godfrin, Y, Koll, R, Perretto, S, Naulet, J, Bouhours, JF \& Soulillou, JP: Antihuman immunoglobulin affinity immunoadsorption strongly decreases proteinuria in patients with relapsing nephrotic syndrome. J Am Soc Nephrol 9:1709-15, 1998

16. Mundel, P, Reiser, J, Zuniga Mejia Borja, A, Pavenstadt, H, Davidson, GR, Kriz, W \& Zeller, R: Rearrangements of the cytoskeleton and cell contacts induce process formation during differentiation of conditionally immortalized mouse podocyte cell lines. Exp Cell Res 236:248-58, 1997

17. Coward, RJ, Foster, RR, Patton, D, Ni, L, Lennon, R, Bates, DO, Harper, SJ, Mathieson, PW \& Saleem, MA: Nephrotic plasma alters slit diaphragm-dependent signaling and translocates nephrin, Podocin, and CD2 associated protein in cultured human podocytes. $J$ Am Soc Nephrol 16:629-37, 2005

18. Hoyer, JR, Vernier, RL, Najarian, JS, Raij, L, Simmons, RL \& Michael, AF: Recurrence of idiopathic nephrotic syndrome after renal transplantation. Lancet 2:343-8, 1972

19. Shalhoub, RJ: Pathogenesis of lipoid nephrosis: a disorder of T-cell function. Lancet 2:556-60, 1974

20. Xu, D, Chan, WL, Leung, BP, Huang, F, Wheeler, R, Piedrafita, D, Robinson, JH \& Liew, FY: Selective expression of a stable cell surface molecule on type 2 but not type 1 helper T cells. J Exp Med 187:787-94, 1998

21. Yanagisawa, K, Naito, Y, Kuroiwa, K, Arai, T, Furukawa, Y, Tomizuka, H, Miura, Y, Kasahara, T, Tetsuka, T \& Tominaga, S: The expression of ST2 gene in helper T cells and the binding of ST2 protein to myeloma-derived RPMI8226 cells. J Biochem (Tokyo) 121:95-103, 1997

22. Yap, HK, Cheung, W, Murugasu, B, Sim, SK, Seah, CC \& Jordan, SC: Th1 and Th2 cytokine mRNA profiles in childhood nephrotic syndrome: evidence for increased IL-13 mRNA expression in relapse. J Am Soc Nephrol 10:529-37, 1999

23. Grimbert, P, Valanciute, A, Audard, V, Pawlak, A, Le gouvelo, S, Lang, P, Niaudet, P, Bensman, A, Guellaen, G \& Sahali, D: Truncation of C-mip (Tc-mip), a new proximal signaling protein, induces c-maf Th2 transcription factor and cytoskeleton reorganization. J Exp Med 198:797-807, 2003

24. Sahali, D, Pawlak, A, Valanciute, A, Grimbert, P, Lang, P, Remy, P, Bensman, A \& Guellaen, G: A novel approach to investigation of the pathogenesis of active minimalchange nephrotic syndrome using subtracted cDNA library screening. J Am Soc Nephrol 13:1238-47, 2002

25. Florido, JF, Diaz Pena, JM, Belchi, J, Estrada, JL, Garcia Ara, MC \& Ojeda, JA: Nephrotic syndrome and respiratory allergy in childhood. J Investig Allergol Clin Immunol 2:136-40, 1992

26. Reeves, WG, Cameron, JS, Johansson, SG, Ogg, CS, Peters, DK \& Weller, RO: Seasonal nephrotic syndrome. Description and immunological findings. Clin Allergy 5:121-37, 1975

27. Wittig, HJ \& Goldman, AS: Nephrotic syndrome associated with inhaled allergens. Lancet 1:542-3, 1970

28. Shimpo, M, Morrow, DA, Weinberg, EO, Sabatine, MS, Murphy, SA, Antman, EM \& Lee, RT: Serum levels of the interleukin-1 receptor family member ST2 predict mortality and clinical outcome in acute myocardial infarction. Circulation 109:2186-90, 2004

29. Brunner, M, Krenn, C, Roth, G, Moser, B, Dworschak, M, Jensen-Jarolim, E, Spittler, A, Sautner, T, Bonaros, N, Wolner, E, Boltz-Nitulescu, G \& Ankersmit, HJ: Increased levels of soluble ST2 protein and IgG1 production in patients with sepsis and trauma. Intensive Care Med 30:1468-73, 2004

30. Tajima, S, Oshikawa, K, Tominaga, S \& Sugiyama, Y: The increase in serum soluble ST2 protein upon acute exacerbation of idiopathic pulmonary fibrosis. Chest 124:1206-14, 2003 
31. Kuroiwa, K, Arai, T, Okazaki, H, Minota, S \& Tominaga, S: Identification of human ST2 protein in the sera of patients with autoimmune diseases. Biochem Biophys Res Commun 284:1104-8, 2001

32. Oshikawa, K, Kuroiwa, K, Tago, K, Iwahana, H, Yanagisawa, K, Ohno, S, Tominaga, SI \& Sugiyama, Y: Elevated soluble ST2 protein levels in sera of patients with asthma with an acute exacerbation. Am J Respir Crit Care Med 164:277-81, 2001

33. Tominaga, S, Yokota, T, Yanagisawa, K, Tsukamoto, T, Takagi, T \& Tetsuka, T: Nucleotide sequence of a complementary DNA for human ST2. Biochim Biophys Acta 1171:215-8, 1992

34. Chenuaud, P, Larcher, T, Rabinowitz, JE, Provost, N, Joussemet, B, Bujard, H, Samulski, RJ, Favre, D \& Moullier, P: Optimal design of a single recombinant adeno-associated virus derived from serotypes 1 and 2 to achieve more tightly regulated transgene expression from nonhuman primate muscle. Mol Ther 9:410-8, 2004 


\section{FIGURE LEGENDS}

Figure 1: Concentrations of soluble ST2 protein in the sera. The level of SST2 was measured by ELISA before and after transplantation in the sera of INS patients with $(R, n=24$ and $n=20)$ or without recurrence $(N R, n=22$ and $n=29)$ and in the sera of proteinuric transplanted patients (non-INS, $n=13$ and $n=22$ ). Significantly higher levels of circulating sST2 are found in recurrent patients after than before transplantation, as well as vs. the other cohorts after transplantation. Statistical differences according to the Wilcoxon rank-sum test are presented: ${ }^{* *}=P<0.001 ;{ }^{* *}=P<0.01$.

\section{Figure 2: Capacity of SST2 to diagnose INS recurrence after transplantation.}

Receiver-Operator-Characteristic (ROC) curves enable a measurement of the ability of SST2 to correctly distinguish patients with INS recurrence from patients with INS non-recurrence (A) or from proteinuric non-INS patients (B). The ROC is represented as a graphical plot of the sensitivity vs. ( 1 - specificity) as the discrimination threshold varies. The sensitivity (or "true positive fraction") represents the capacity of the test to distinguish patients with recurrence, and the sensitivity is its ability to detect non-recurrent or proteinuric control patients. Thus, ( 1 - specificity) is also called "false positive fraction". Finally, the capacity of the test to discriminate recurrent and control patients is measured by the area under the ROC curve (AUC), with an AUC of 1.0 corresponding to a perfect test.

Figure 3: Two-dimensional analysis of the SST2 protein in recurrence. Eluate obtained after immunoprecipitation of SST2 from the plasma of a recurrent INS patient was tested by bidimensional electrophoresis using a $\mathrm{pH}$ range of 3 to 10. Areas indicated on the gels were further analyzed by mass spectrometry.

Figure 4: Effects of sera from INS patients with or without recurrence on podocytes in vitro. Differentiated podocytes were incubated with different sera. A final concentration of $10 \%$ serum was applied to the cells for $48 \mathrm{~h}$. Representative panels for each experiment are indicated. (A) FCS alone. (B) Reactive serum from patient with INS recurrence. (C) Serum from patient with INS non-recurrence. Immunofluorescence double staining was performed with anti-F actin (red), anti-vinculin (green) antibodies and DAPI (blue) on podocytes following incubation with FCS (D), reactive serum from INS recurrence (E) and serum from INS non-recurrence (F).

Figure 5: Effects of the different fractions from anti-sST2 column on podocytes in vitro. SST2 of reactive plasmas from INS recurrence was purified on an anti-sST2 column. 
The activity of each fraction was tested on the podocyte cell line $(10 \%, 48 \mathrm{~h})$. Representative panels for each experiment are shown. (A) FCS alone. (B) Initial plasma. (C) sST2-depleted plasma. (D) Purified SST2. Immunofluorescence with anti-F actin (red), anti-vinculin (green) antibodies and DAPI (blue) after incubation with FCS (E), initial plasmas (F), sST2-depleted plasmas $(\mathbf{G})$ and purified SST2 proteins $(\mathbf{H})$.

Figure 6: Effects of the intravascular administration of AAV8-sST2 into healthy SPD rats. (A) Serum SST2 concentrations were measured by ELISA at different time points after injection. (B) Proteinuria levels were measured in urine after injection. Data are expressed as mean protein $(\mathrm{g} / \mathrm{L}) / \mathrm{creatinine}(\mathrm{mmol} / \mathrm{L}) \pm \mathrm{SD}$ (scale bars).

Figure 7: Proteinuria after injection of purified SST2 into the rat vasculature. Urine was collected at different time points after injection. Data are expressed as mean protein $(\mathrm{g} / \mathrm{L}) /$ creatinine $(\mathrm{mmol} / \mathrm{L}) \pm \mathrm{SD}$ (scale bars). 


\section{TABLES}

Table 1. Clinical characteristics of INS patients with or without recurrence after kidney transplantation (Tx) and proteinuric controls (non-INS).

\begin{tabular}{|c|c|c|c|}
\hline & \multicolumn{3}{|c|}{ AFTER TRANSPLANTATION } \\
\hline & $\begin{array}{c}\text { INS } \\
\text { Recurrence } \\
n=31\end{array}$ & $\begin{array}{c}\text { INS } \\
\begin{array}{c}\text { Non-recurrence } \\
n=40\end{array}\end{array}$ & $\begin{array}{c}\text { Non-INS } \\
n=34\end{array}$ \\
\hline Gender & $17 \mathrm{M} / 14 \mathrm{~F}$ & $22 \mathrm{M} / 18 \mathrm{~F}$ & $27 \mathrm{M} / 4 \mathrm{~F}$ \\
\hline $\begin{array}{l}\text { Mean age at Tx } \\
\text { (years) }\end{array}$ & $28.7[18-52]$ & 39 [12-58] & $41[20-58]$ \\
\hline $\begin{array}{l}\text { Duration of HD } \\
\text { (months) }\end{array}$ & $37.8[0-140]$ & 38 [0-127] & 31.4 [0-104] \\
\hline $\begin{array}{c}\text { Transplantation } \\
\text { Rank }\end{array}$ & $\mathrm{G} 1=26, \mathrm{G} 2=4, \mathrm{G} 3=1$ & $\mathrm{G} 1=33, \mathrm{G} 2=6, \mathrm{G} 3=1$ & $\mathrm{G} 1=30, \mathrm{G} 2=4$ \\
\hline $\begin{array}{l}\text { Time after Tx } \\
\text { (months) }\end{array}$ & 14 [1-134] & 38 [1-184] & 60 [6-165] \\
\hline $\begin{array}{l}\text { Serum } \\
\text { creatinine } \\
(\mu \mathrm{mol} / \mathrm{L})\end{array}$ & $175[80-420]$ & 140 [74-228] & 247 [116-435] \\
\hline $\begin{array}{l}\text { Proteinuria } \\
\text { (g/24h) }\end{array}$ & $4.5[2.5-10]$ & $0.14[0-0.46]$ & $43[3-6.2]$ \\
\hline IS regimen & $\begin{array}{l}\text { CNI + MMF or AZA } \\
100 \% \text { under CS }\end{array}$ & $\begin{array}{l}\text { CNI + MMF or AZA } \\
46 \% \text { under CS }\end{array}$ & $\begin{array}{c}\text { All CNI + MMF or AZA } \\
\text { But one AZA } \\
88 \% \text { under CS }\end{array}$ \\
\hline
\end{tabular}

HD: Hemodialysis, IS: Immunosuppressive, CNI: Calcineurin Inhibitors, MMF: Mycophenolate Mofetil, AZA: Azathioprin, CS: Corticosteroids.

Patients were roughly matched for number of transplantations, HLA compatibility, pre-graft panel reactive antibodies, type of treatment, duration of delayed graft function and maintenance immunosuppressive therapy. Intrinsically to the definition of the group, INS recurrent patients were younger than non-INS patients $(P<0.001)$ and their proteinuria levels were significantly higher compared to non-recurrent patients $(P<0.0001)$. In addition, sera were obtained later after transplantation for non-INS patients $(P<0.01)$ compared to recurrent patients, but their proteinuria levels remained similar. 
Table 2. Sequence of peptides corresponding to the human sST2 protein identified by mass spectrometry in the cluster of spots \#1.

\begin{tabular}{lccc}
\hline \multicolumn{1}{c}{ Sequences } & Start & End & $\begin{array}{c}\text { Observed Mass } \\
(\mathrm{kD})\end{array}$ \\
\hline QSWGLENEALIVR & 23 & 35 & 758 \\
VFASGQLLK & 65 & 73 & 481 \\
FLPAAVADSGIYTCIVR & 74 & 90 & 927 \\
QSDCNVPDYLMYSTVSGSEK & 108 & 127 & 1140 \\
SFLVIDNVMTEDAGDYTCK & 164 & 182 & 1089 \\
DEQGFSLFPVIGAPAQNEIK & 204 & 223 & 1080 \\
\hline
\end{tabular}


Figure 1

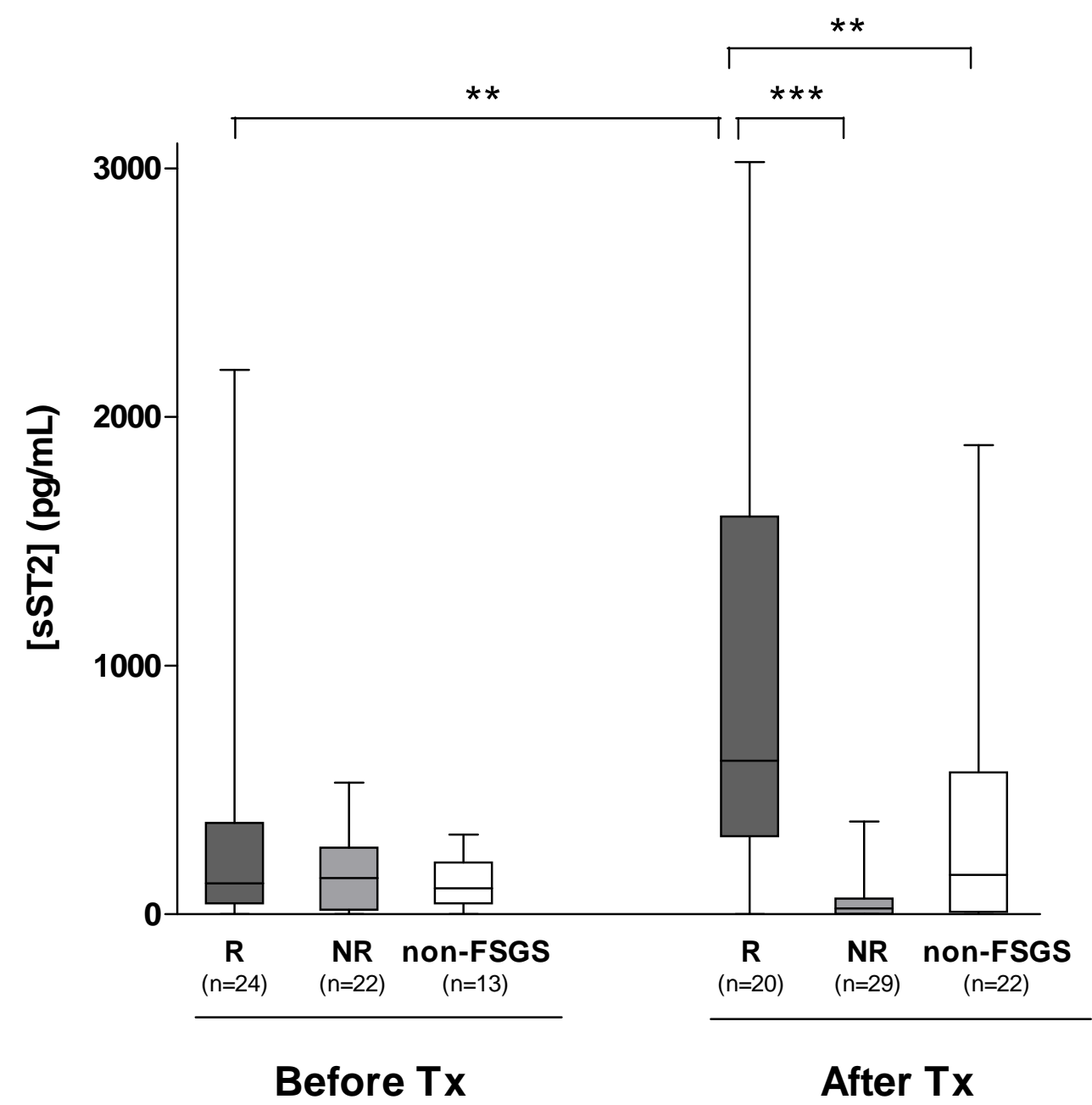


Figure 2

A

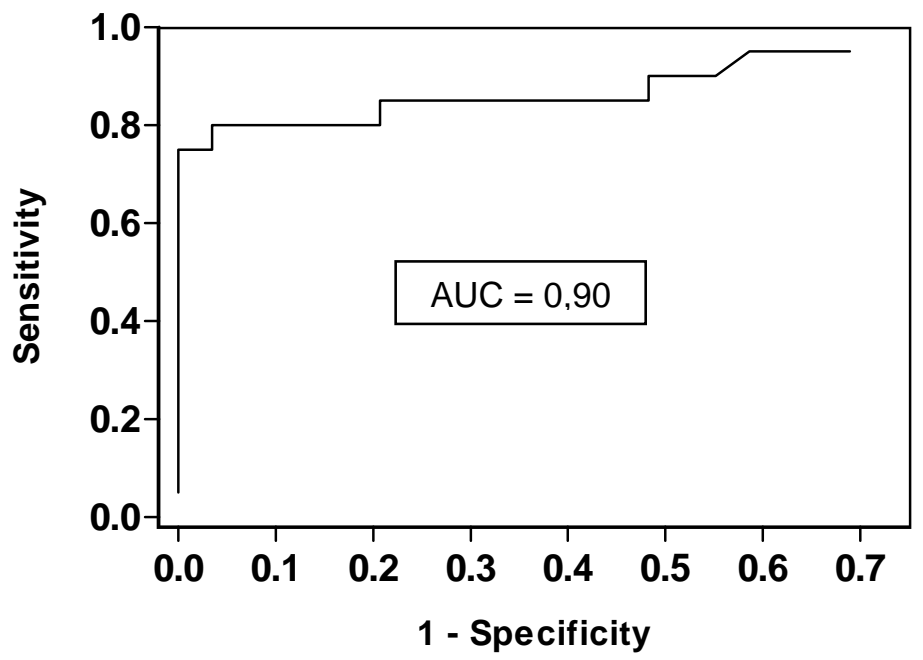

B

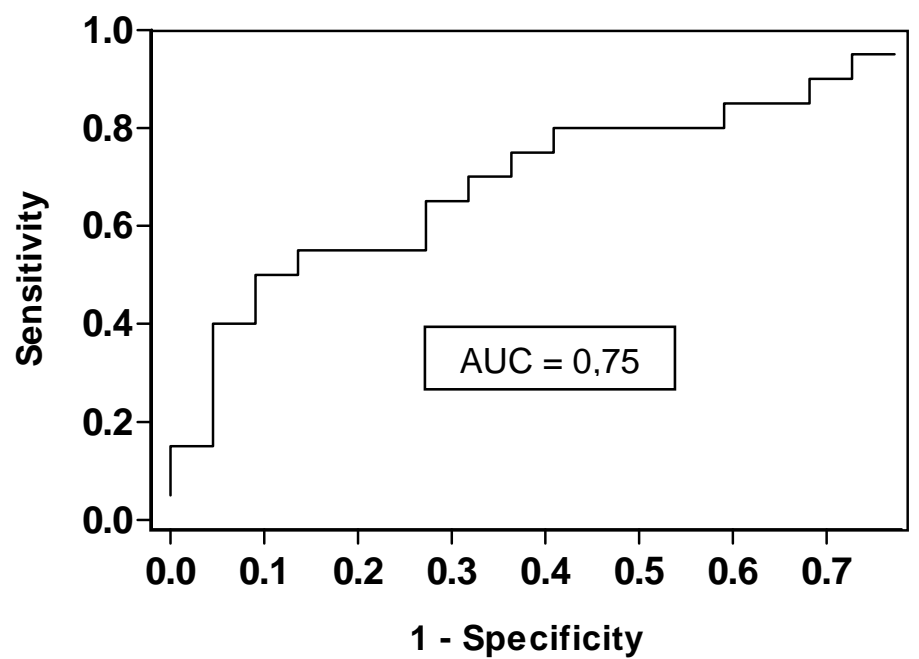


Figure 3

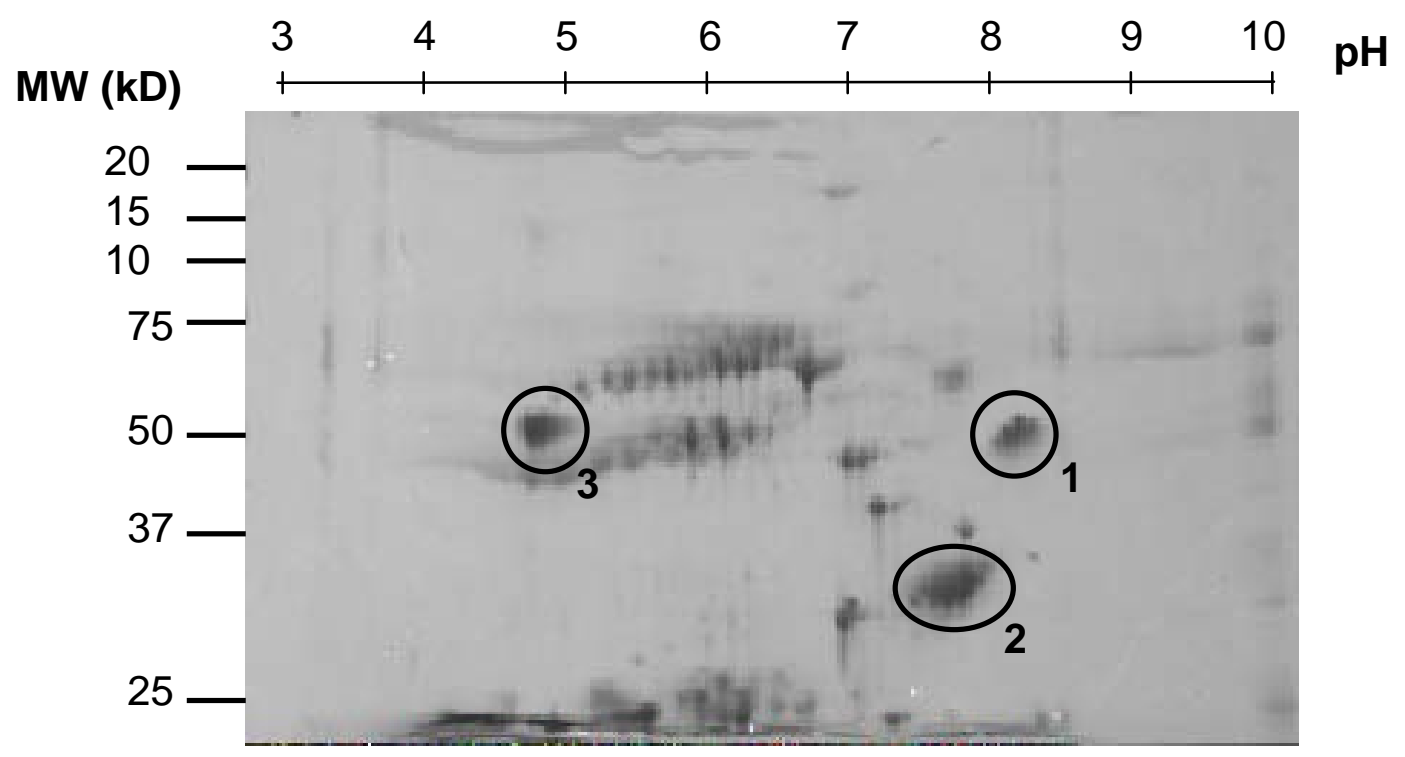


Figure 4

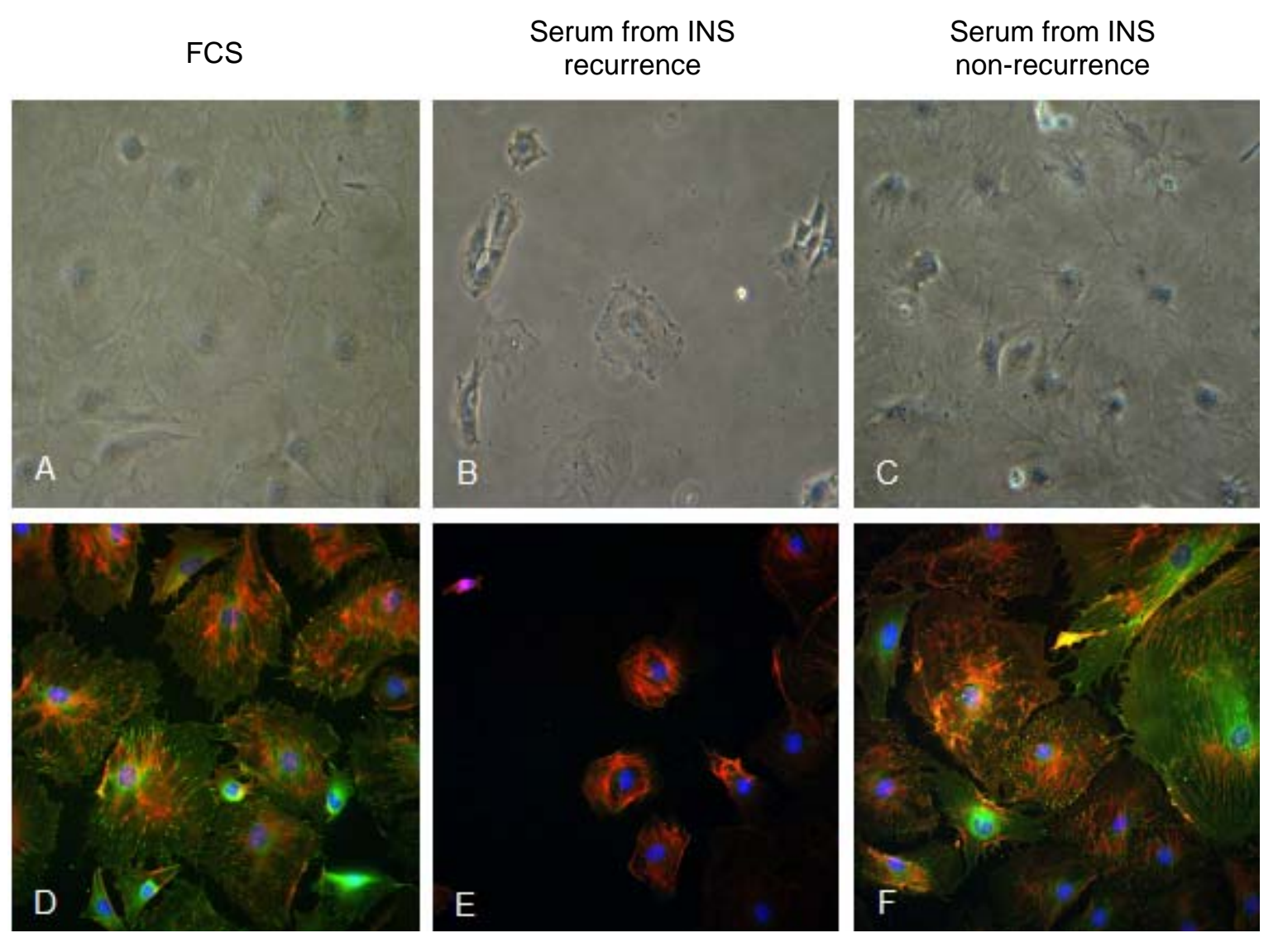


Figure 5
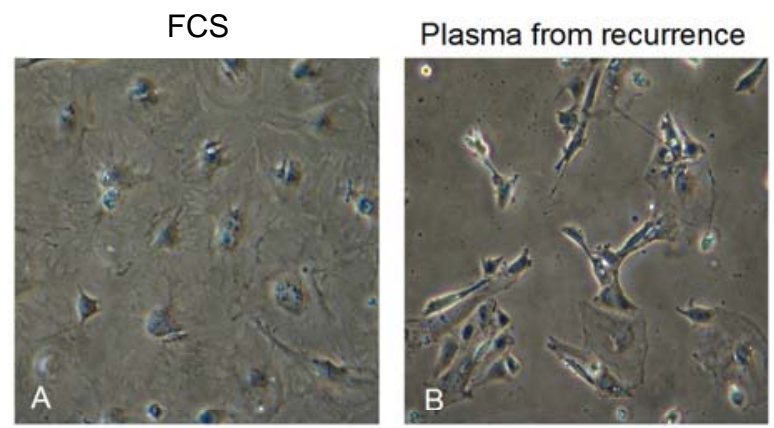

sST2-depleted plasma
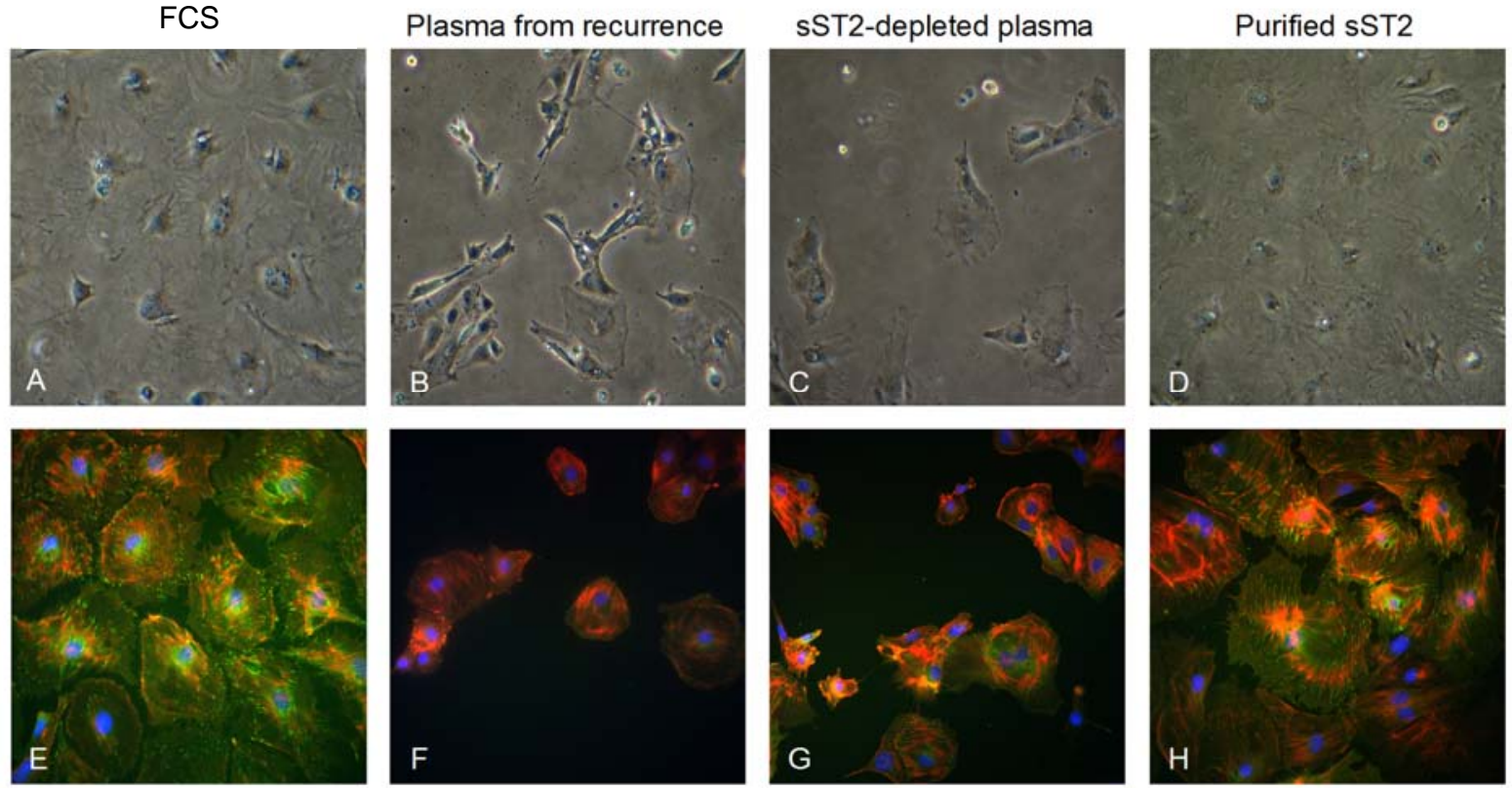
Figure 6

A

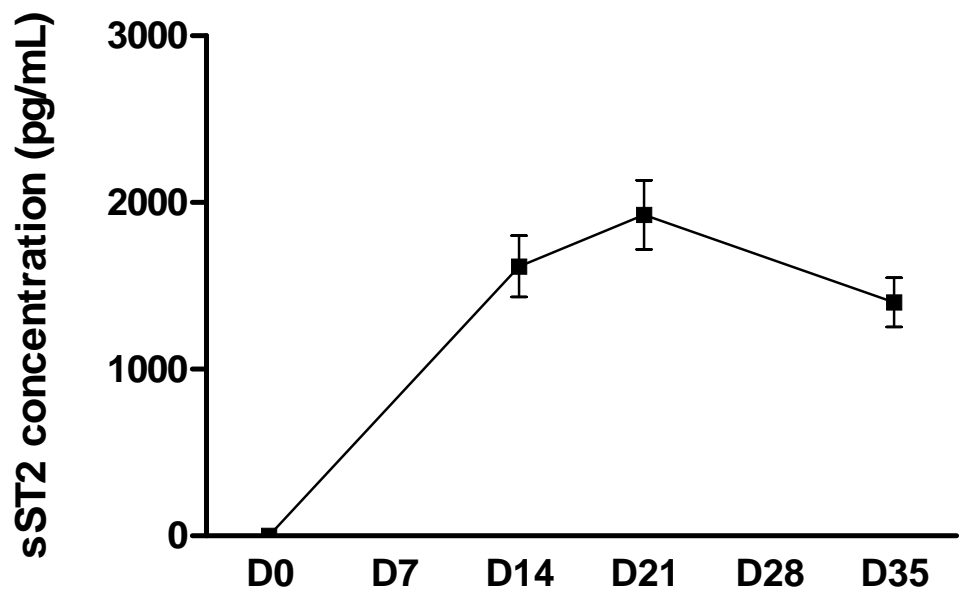

B

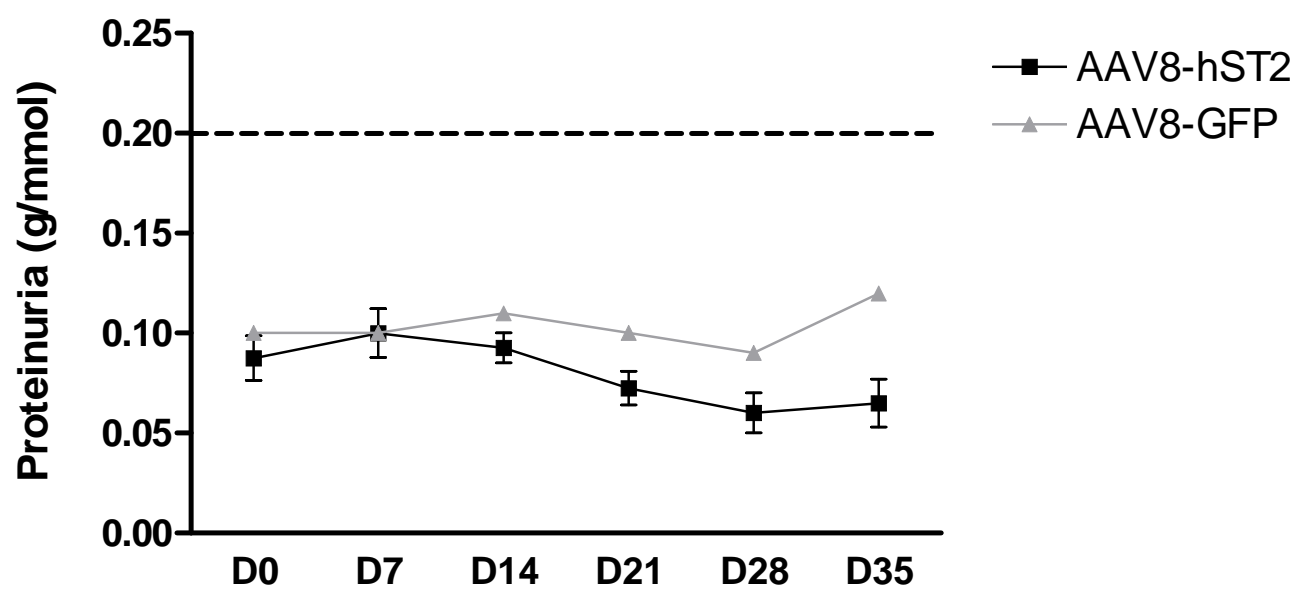


Figure 7

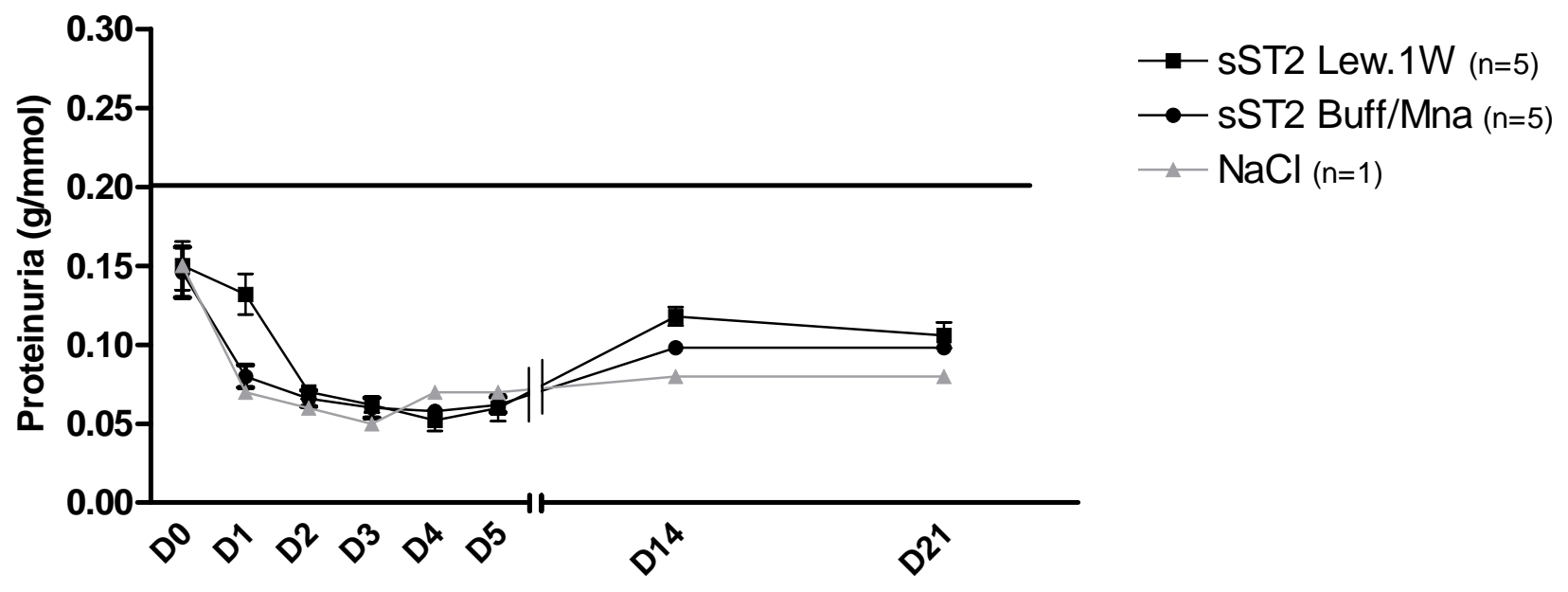

